\title{
Horizontes Comerciais, Políticos e Literários na Imprensa de Floriano entre os Anos 1902 e $1921^{1}$
}

Resumo:

Os primeiros vinte anos do século XX foram de grande transformação à cidade de Floriano, considerada, na época, um dos polos ativos do comércio importador-exportador do estado do Piauí, no hinterland do Brasil. Nesse recorte histórico o periodismo jornalístico e literário surgiu e testemunhou as mudanças de hábito de sua sociedade, que assistia à chegada dos ares modernos. Favoráveis a essa transformação, as conjunturas comercial e política operadas pelo Partido Republicano, sobremodo entre os anos de 1916 e 1924, foram responsáveis por formar no município um dos significativos circuitos literários do estado e, consequentemente, se vivenciasse em redações de jornais e agremiações literárias eventualidades culturais, bem como aparelhos de sociabilidade como teatro, cinema e clubes - índices de uma vida literária relativamente ativa. Este artigo analisa essas mudanças e suas resistências, partindo do ano de 1902, quando é fundado o primeiro periódico na cidade, ao ano de 1921, fim da primeira fase do jornal mais importante do período, 0 Popular.

Palavras-chave:

periodismo, vida literária, Floriano, política e comércio.

\section{Abstract:}

The first twenty years of the 20th century were of great transformation to the city of Floriano, considered, at the time, one of the active hubs of the import-export trade in the state of Piauí, in the hinterland of Brazil. In this historical context, journalistic and literary journalism emerged and witnessed the changes in habits of its society, which was witnessing the arrival of modern airs. Favorable to this transformation, the commercial and political conjunctures operated by the Republican Party, especially between the years 1916 and 1924, were responsible for forming in town one of the significant literary circuits of the state and, consequently, as if it had been experienced in newsrooms of newspapers and literary associations, cultural environment such as theater, cinema and clubs - evidence of a relatively active literary life. This article analyzes these changes and their resistance, starting in 1902, when the first periodical was founded in the city, in 1921, the end of the first phase of the most important newspaper of the period, $O$ Popular.

\section{Keywords:}

periodism, literary life, Floriano, politics and trade 
Localizada no sudoeste do estado do Piauí, em pleno hinterland do nordeste brasileiro, a história da cidade de Floriano registra ocorrências favoráveis aos estudos comparatistas em literatura, imprensa, política e economia, sobretudo nas primeiras décadas do século XX, quando essas áreas tanto condicionaram exercícios jornalísticos como atuaram na defesa ou na manutenção de um status quo político-partidário. Os escritores, porta-vozes dessa conjuntura, desempenharam um importante papel nas lides de imprensa, onde a atividade literária muitas vezes se confundia à política ao adotar um discurso doutrinário em favor de determinada bandeira política - no caso desta investigação, os ideais do Partido Republicano, antigo grupo político brasileiro de viés conservador e, no Piauí, expressão dos interesses da elite agropastoril que dominava vastas extensões de terra nas mesorregiões sudeste e sudoeste.

Para entender o desenho intelectual que aqui se esboça, é necessário registrar que nas últimas três décadas da República Velha o espaço intelectual piauiense se organizava em três circuitos literários distintos, intimamente identificados com estruturas específicas de poder. Estas não apenas os normatizava como tornavam possíveis as suas existências: ao norte, caracterizadamente ligado às estruturas e interesses mercantis de uma elite comercial relativamente cosmopolita (guardadas as limitações histórico-espaciais), e em geral formado por escritores empregados do comércio e comerciantes médios; ao centro-norte, relacionado direta ou indiretamente aos três poderes do estado e constituído em geral por bacharéis, engenheiros ou médicos - filhos de membros da alta elite agropastoril; e um terceiro ao sul (coordenada tomada aqui em acepção genérica às duas mesorregiões que a constituem, a sudoeste e a sudeste), identificada tanto com as esferas do poder político como econômico - ademais, o nível educacional de seus literatos girava em torno da formação superior e do preparativo técnico.

Acresce-se que dentro dessas estruturas, agremiações literárias estudantis também atuaram no campo e suas operações foram de suma importância à história literária em cada um dos três espaços, sobremodo atividades na vida literária propriamente dita e protagonismo em uma imprensa especializada. Em termos espaciais, vale destacar mais um aspecto quanto à constituição desses circuitos literários piauienses: no norte, era seu núcleo a cidade de Parnaíba, no litoral; no centro-norte, a capital do estado, Teresina; e no sul, a cidade de Floriano - as duas últimas internadas no estado.

O entendimento da formação deste último circuito e suas consequentes relações com o poder foi possível quando se investiu o olhar sobre as diversas estruturas que viabilizaram uma conformação simbólica, cujos rastros, deixados em fontes primárias hemerográficas, demonstram os diversos horizontes de sua classe política e intelectual.

\section{Horizontes do poder econômico}

A imprensa em Floriano tem uma história que, comparada a de outras cidades do Piauí, começou tarde. No entanto, ao se avaliar que até os anos de 1870 o espaço não passava de um simples povoado, o aparecimento de seu primeiro periódico, em 1902, foi uma circunstância relativamente rápida, reflexo da celeridade de conformação do município como o entreposto comercial mais importante do sul do estado desde a elevação da Colônia São Pedro de Alcântara 
à categoria de município, em 1897. A nova cidade, portanto, ao desempenhar esse papel, substituiu a velha Amarante, que já nos anos de 1910 havia perdido o protagonismo como empório e então apostava as esperanças econômicas na cotonicultura.

Assim firmada, Floriano escoava importados do norte e exportava matérias-primas das porções sudoeste e sudeste do Piauí - fluxo realizado por intermédio do rio Parnaíba, o segundo mais importante do nordeste brasileiro. Nesse sentido, e em conjunto com a cidade de Parnaíba, representava um dos pontos de grande afluência do comércio que se realizava ao longo dessa artéria fluvial.

A partir de 1917, quando a Associação Comercial de Parnaíba foi fundada, a viabilidade dos produtos e matérias-primas piauienses em praças comerciais internacionais ganhou impulso logo após requisições, junto à presidência da República, promovidas por essa instituição capitalista que agregava alguns dos homens mais ricos do Piauí. Esta conjuntura ajuda a explicar o desenvolvimento de núcleos populacionais, até então recentes, que dependiam direta ou indiretamente de atividades subordinadas ao referido rio.

Por estar em situação geográfica privilegiada e internada no interior (região de intensa atividade agropecuária), a cidade de Floriano foi um dos espaços que usufruiu de intensas relações econômicas, daí por que tenha afirmado o historiador Luiz Paulo Lopes (1997: 32) que "os vapores que atracavam no cais de Floriano [...] eram vapores de passageiros, além de levarem a reboque várias barcas carregadas de mercadorias, víveres e outros produtos trazidos de Parnaíba e Teresina"; ao que completa, "nosso porto era movimentadíssimo e em determinados dias podiam ser vistos ancorados aqui, até dez vapores. Os vapores faziam carreira entre Parnaíba até o porto de Balsas, no Maranhão, num intercâmbio constante". O movimento "em determinados dias", na realidade, era um fator prejudicial aos negócios, como atesta nota publicada em 0 Popular, de 1921:

Vezes há, que atracam em nosso porto e quase que de uma só vez, pois são pequenos os intervalos, quatro, seis, oito e mais embarcações a vapor, mas, em compensação e como que em represália a essa pletora nociva, como nocivas são todas as superabundâncias, também passamos seis, oito, dez e mais dias, sem recebermos sequer uma única visita de um só dos barcos que fazem a nossa navegação fluvial. ${ }^{2}$

A razão dos intervalos estendidos era mais de ordem comercial e logística do que de formação geológica, afinal, esta era favorável à navegação. Segundo deixa entrever Junia Rego, de Floriano até o norte, o rio Parnaíba tinha um leito fluvial composto de pedra. Algo diferente ocorria rumo ao sul, até Uruçuí, "arenoso e composto de uma areia movediça, que podia mudar de lugar de um dia para outro" (Rego 2013: 73). Isso implicava profundidades distintas ao longo dos dois transcursos do rio: "de 0,7 a 1,00m de calado de Uruçuí a Floriano e daí à cidade de Parnaíba 1,50m" (Gandara 2010: 66).

O primeiro periódico fundado em Floriano foi o mensário Vida Comercial, no ano de 1902. $\mathrm{O}$ expediente dessa folha atendia à composição socioeconômica que sustentava a cidade e 
viabilizava a circulação de algum órgão de imprensa. Apesar de taxativamente comercial, o jornal mantinha os leitores atualizados dos acontecimentos que movimentavam as principais praças do Brasil. Sua tiragem era mínima devido ao contingente populacional do município, que nos primeiros anos do século XX não contava seis mil habitantes, de uma média de 600 a 700 mil que havia em todo o Piauí, segundo o censo realizado em 1920.

Em conjunto com outras cidades piauienses, a "Princesa do Sul", como ficou conhecida, nasce sob o signo da pecuária, mas a pujança de seu empório comercial é alcançada pela produção e comercialização de produtos de origem vegetal, como a maniçoba nos últimos anos do século XIX. Já nas primeiras décadas do século XX, o município manteve intenso comércio de equivalentes como coco babaçu, arroz, milho, feijão, bem como manufaturas do tipo rapadura, tapioca e cera de carnaúba. Neste rol ainda entravam produtos de origem animal, como pele de cabra, pele de ovelha e penas de ema; e outros com menor valor de mercado na época: mamona, algodão em caroço, resinas de jatobá e de angico.

Assim, Vida Comercial estava intimamente relacionado ao corpo social capitalista instalado à beira do rio Parnaíba, fato que ilustra a observação de Benedict Anderson acerca dos primeiros jornais norte e sul-americanos, que "começaram basicamente como apêndices do mercado" (Anderson 2008: 102). Ao viabilizar uma estrutura de informações à classe do comércio, o jornal, correlacionado a outras folhas congêneres que existiam tanto em Teresina como em Parnaíba, integrou os habitantes da cidade a uma espécie de "comunidade imaginada" existente no Piauí. Em obediência à morfologia da tese, a língua desta comunidade era a dos preços, dos horários de navios e das mercadorias, e sua imprensa, parcialmente desligada da política (pelo menos em um primeiro momento), não escondia o serviço que prestava ao capitalismo.

Tal realidade permitiu a Floriano uma identificação, em maior ou menor grau, com os comerciantes de outras praças, sobretudo os de Parnaíba - o outro polo dessa mesma estrutura. ${ }^{3}$ Isso sugere que a comunidade não estava restrita a um espaço, e nem é isso o que Anderson propõe em sua operação, ela era desterritorializada, sendo a imprensa um dos suportes de trocas comunicacionais de uma língua comum, o capital. Não por acaso, "em termos histórico-mundial, a burguesia foi a primeira classe a construir uma solidariedade a partir de uma base essencialmente imaginada" (Anderson 2008: 119).

Em perspectiva ampla, mas não tão universal ou genérica - corte necessário à análise -, essa lógica ajudaria a entender outros vínculos que o Piauí estabeleceu cultural e economicamente com espaços vizinhos, dentre os quais o estado do Maranhão, que, no período da República Velha e com relativo destaque, não apenas serviu de porto ao escoamento de mercadorias advindas e chegadas ao Piauí como, muitas vezes, foi o local de formação intelectual de inúmeros piauienses, alguns antes mesmo de migrarem para Pernambuco, atraídos pela Faculdade de Direito de Recife.

Da fundação de Vida Comercial, demoraria aproximadamente dez anos para que outros veículos de imprensa surgissem na cidade: o propagandista Serip, título anagramático de um dos sobrenomes de seu proprietário, João Pires Ferreira; e o primeiro de cunho noticioso e com temáticas variadas, O Popular. Fundado em 27 de novembro de 1912, na linha de sucessão dos 
veículos de imprensa fundados em Floriano, foi, talvez, o segundo ou o terceiro a aparecer.

Criado como empresa, este jornal resistiu por longos 23 anos, de 1912 a 1934. ${ }^{4}$ Essa durabilidade se deveu à adoção de várias estratégias: venda de exemplares, anúncios e assinaturas, bem como a comercialização de serviços gráficos em sua tipografia. Tinha como redator-chefe uma figura então conhecida: Daniel Paz, juiz de Direito em Floriano e, no campo literário teresinense, sonetista que, pelo menos desde o final do século XIX, tinha espaço tanto na imprensa periódica da capital do Piauí quanto de cidades maranhenses ${ }^{5}$ por influência política, comercial e jornalística de sua família. Era seu pai o capitão Firmino Alves Cardoso Paz e seu irmão, Tersandro Paz, que havia sido intendente em Teresina, proprietário da Farmácia Popular e de oficinas tipográficas que alimentariam o periodismo na capital nos anos de 1910. Além disso, seu tio, Manuel da Paz, foi vice-governador do Piauí. Vale ressaltar que Daniel tinha como sócio e correligionário José Pires Ferreira, diretor-proprietário da referida folha e antigo dono do Serip. Ferreira era membro de uma família que por longos anos dominou a política no estado sob a égide do Partido Republicano Piauiense.

Essas vinculações ajudam a compreender não apenas a rede de relações do redator-chefe da folha, como a fundação de um periódico de mesmo nome (excetuando o artigo inicial) em Parnaíba, no ano de 1902, dirigido por Júlio de Paiva Rosa, irmão de Miguel de Paiva Rosa, governador do Piauí entre os anos de 1912 e 1916, estes filhos de João Rosa, cunhado de Manuel da Paz. ${ }^{6}$ Apesar da vinculação, e como a política era e é uma instância de acordos e tratativas partidárias flutuantes, vê-se em 1919 um O Popular contrário a Miguel Rosa, a alimentar ranço mesmo após o término de seu mandato no executivo estadual, "a página mais triste da nossa história". ${ }^{7}$

Foi em Parnaíba que o jovem Daniel exerceu inicialmente o cargo de juiz distrital. Nesse período efetuara contato com a classe comercial e literária do norte piauiense. Daí a razão de ter publicado, entre os anos de 1910 e 1911, no jornal parnaibano Semana, folha noticiosa e de interesse comercial. Tal circunstância seria alterada neste ano, quando Firmino Paz falece e Daniel retorna a Teresina para ocupar o cargo deixado pelo pai, o de administrator dos Correios do Piauí. Portanto, antes de iniciar o periodismo em Floriano, Daniel Paz tinha história no setor jornalístico e na política em Teresina, conjuntura ideal para uma atividade que não parecia destoar de interesses partidários e pessoais.

Se as referidas conjunturas se mostravam favoráveis, o mesmo não pode ser afirmado do histórico parental de Daniel Paz como decisivo à impressão de 0 Popular em Teresina. Sabe-se, todavia, que pelo menos em 1918 o periódico era impresso em Floriano: sua oficina tipográfica estava localizada na Praça do Mercado. Por essa década, importante destacar que a atividade comercial da cidade contava com firmas que agenciavam insumos e produtos de praças estrangeiras, a citar a Fonseca Borges \& Cia, que desde 1910 vinha estabelecendo relações com empresas sediadas em Paris, Hamburgo e Londres, com venda a grosso e a varejo - época que o município prosperou com o advento da exportação da borracha de maniçoba.

Válida a contribuição de sírios e libaneses para os negócios citadinos, quando nas primeiras décadas do século XX o estado os recebeu tanto em Teresina como em Floriano, e eles 
Cadernos de Literatura Comparada

Horizontes Comerciais, Políticos e Literários na Imprensa de Floriano entre os anos de 1902 e 1921

tiveram "significativa participação no comércio dessas cidades, essencialmente comerciais e que já exerciam influência inclusive nas cidades vizinhas do Maranhão" (Tajra/Tajra Filho 1995: 143). A presença dos sírios nas páginas dos primeiros periódicos de Floriano será uma constante em anúncios comerciais, não por acaso o estabelecimento desses estrangeiros no comércio coincide com os primeiros empreendimentos jornalísticos do espaço:

Em Floriano, o primeiro a chegar foi Gabriel Zarur, em 1890, que montou a "Padaria Zarur", sendo seguido por muitos outros, dentre os quais, José Demes, em 1908 (José Demes \& Filhos ferragens), Adala Attem (Casa Adala Attem - tecidos), Salomão Mazuad, em 1910 (Casa Salomão Mazuad \& Cia - bazar e material de construção), Calixto Lobo, em 1912 (Calixto Lobo \& Cia bazar) e, ainda, Salomão Barguil, em 1915, David Mazuad, em 1923 e Hagem Mazuad, em 1947. (Tajra/Tajra Filho 1995: 143-144)

Os vínculos com o estrangeiro que ajudaram a construir a sociedade comercial e, posteriormente, a intelectual, também colocaram o município em uma situação de calamidade pública: ao final de 1918 o surto da "gripe espanhola" chegou à população a bordo dos mesmos navios a vapor que viabilizavam seu comércio. O vírus não era desconhecido e já havia abatido pelo menos 25 mil vidas só no Rio de Janeiro e em São Paulo, além do rastro violento de 20 milhões de mortes em todo o mundo. Notas ao longo do ano de 1918, publicadas na imprensa de Floriano, davam conta do surto em outros estados brasileiros, inclusive no vizinho Maranhão, bem como em cidades piauienses como Picos, Jaicós e Oeiras. Quanto à chegada ao município, é o jornal O Popular quem noticia a pandemia, a apontar a culpa de seu agravamento ao inspetor sanitário do estado, que, em sabendo da calamidade que acometia Teresina, não impedira o fluxo de passageiros ao sul piauiense: "a nossa cidade está cheia de doentes da perigosa moléstia [...]. Hoje pela manhã chegará o 'Piauí', e nele, segundo consta, virão muitos gripados para esta cidade, como se aqui fosse um posto de isolamento". ${ }^{8}$ A nota finaliza com um reclame mais incisivo: "a coisa vem lá da capital do Estado, e nós sertanejos curvamo-nos, reverentes". 9

Considerada até então a mais terrível epidemia experimentada pelo mundo, o saldo total de mortos que a doença deixara no Brasil alcançou o patamar de 300 mil mortos, o equivalente a mais ou menos $1 \%$ de toda a sua população na época.

\section{Horizontes do poder político}

Essencialmente noticioso, 0 Popular mantinha como coluna fixa as notícias que chegavam ao sul piauiense via telegrama, vertendo para as suas páginas as que mais importavam à conjuntura estadual e nacional. Além disso, era costume a reprodução de textos de colunistas de importantes folhas cariocas, dentre as quais A Noite, O País e A Época. Foi assim que o jornal divulgou alguns dos eventos históricos mais significativos que cobrem as três primeiras décadas do século XX, como a I Guerra Mundial, a seca que assolou o Piauí em 1915, a referida "gripe espanhola", a tentativa de cientistas brasileiros para a cura ou o tratamento para a morfeia (hanseníase), o sufrágio universal e a política brasileira entre os anos de 1918 e 1919, que tinha 
como candidatos à presidência da República Epitácio Pessoa e Rui Barbosa.

Porque seguiam o voto de Eurípedes de Aguiar, então governador do Piauí, os diretores de O Popular, ligados ao Partido Republicano, apoiavam Epitácio Pessoa. Logo, a candidatura de Rui Barbosa não era recebida com simpatia e o jornal publicava na capa de suas edições textos contrários ao então senador, julgando-o pela vaidade em detrimento da competência. Aliás, havia da parte dos jornalistas que atuavam na folha muita desconfiança a respeito da capacidade do político baiano de dirigir a nação. Essa suspeição, porém, não era transmitida para o perfil intelectual de Rui Barbosa, reverenciado nos inúmeros textos de sua autoria publicados em primeira página. A circunstância dual, entre o cabresto político e o preito de admiração, poderia ser sintetizada no trecho de um dos textos que o periódico publica em abril de 1919: "o Conselheiro Rui Barbosa é uma relíquia da pátria, mas, não é a encarnação da pátria" ${ }^{10}$

Mais tarde, por simpatia ao poeta piauiense Félix Pacheco, os editores do jornal investiram na candidatura de seu irmão, João Luís Ferreira, ao governo do Piauí - pleito vencido em 1920, sucedendo Eurípedes de Aguiar. Neste mesmo ano, para o quadriênio 1921-1924, Floriano deu vitória esmagadora aos candidatos do mesmo Partido Republicano, tanto para os cargos de intendente (Antônio Luís de Arêa Leão), vice-intendente (tenente-coronel Frutuoso Pacheco Soares) como para os conselheiros municipais, ${ }^{11} \mathrm{em}$ uma rara conjuntura que fez correligionários do mesmo partido nos três níveis do executivo, o municipal, o estadual e o federal, além de um legislativo munícipe igualmente favorável. Vale lembrar que Luís de Arêa Leão sucede um colega do mesmo partido na intendência municipal, Raimundo Borges da Silva, ${ }^{12}$ lançado como vice na chapa vitoriosa do governador João Luís Ferreira.

No Rio de Janeiro, Félix Pacheco se tornou um dos mais fortes e significativos representantes políticos de um Piauí conservador e oligárquico, quando por um largo período de tempo esteve ao lado dos presidentes republicanos, ora no senado, ora como ministro. Ao suceder Epitácio Pessoa, por exemplo, Artur Bernardes nomeia o piauiense como chanceler e foi nesta condição que o poeta de Marta vencera, em 1922, a luta de braço travada com Francisco de Assis Chateaubriand para a compra do Jornal do Comércio, o mais antigo periódico em circulação do continente. Ao impedir pela via política o negócio do jornalista paraibano com Antônio Ferreira Botelho, proprietário da folha carioca naquela época, Félix Pacheco, logo no ano seguinte, adquire os direitos sobre a marca e se torna seu diretor-proprietário. Esse fato tem reflexos na política e na literatura piauiense: primeiro, a posse de um veículo de imprensa tão influente e poderoso deu ao piauiense a oportunidade de manter seu prestígio e o prestígio de seu partido nas lides políticas; e, segundo, serão em suas oficinas que muitos intelectuais conterrâneos de Pacheco imprimirão obras, nos mais variados gêneros.

Nesse tempo a força do Partido Republicano Piauiense era apenas um reflexo tardio de seu epicentro nordestino, localizado em Recife, e que desde o século XIX fizera nomes importantes na conjuntura política nacional, sobretudo governadores de estados estratégicos. Foi seu líder por muitos anos Francisco de Assis Rosa e Silva, político recifense que no período de 1898 a 1902 exerceu o cargo de vice-presidente de Campos Sales. Seu poder de influência, nas palavras de Fernando Morais (1999: 69), o tornava "o mais acabado modelo de oligarca nordestino", 
tendo ajudado a construir o poderio do partido em Pernambuco ao fazer, de 1896 a 1911 (quando uma revolta violenta em Recife põe no cargo o general Dantas Barreto), inúmeros governos consecutivos, dentre eles o de Sigismundo Antônio Gonçalves, ${ }^{13}$ o segundo piauiense a comandar o executivo pernambucano - o primeiro foi José Manuel de Freitas, entre 1883 e 1884. Os piauienses magistrados formados na Escola de Recife, porque desde o século XIX ao retornarem ao Piauí ingressavam nas lides políticas, inevitavelmente refletiram esse mesmo fenômeno político partidário, a reproduzir à sua maneira - e para interesse das elites - os jogos de poder oligárquico e sustentação de audiência e transmissão de ideias por meio da imprensa. Daniel Paz, um desses bacharéis de geração novecentista, era ainda um vestígio de tal conjuntura.

Se por um lado esse tipo de articulação política sufocou o debate democrático ao desmontar a oposição no Piauí, por outro, foi de suma importância às porções internalizadas do estado, afinal, de Raimundo Borges da Silva a Luís de Arêa Leão e de Eurípedes de Aguiar a João Luís Ferreira a cidade de Floriano e o estado do Piauí foram, respectivamente, governados oito anos consecutivos por políticos do PRP intimamente ligados ao município, o que permitiu à região sudoeste-sudeste, mesmo em período assolado pela profunda crise econômica de depressão cambial do pós-guerra, gozar de benefícios, bem como impor a voz em um cenário de relevância político-partidária. A condição de vinculação a duas estruturas, a política e a comercial, fez com que a cidade atravessasse o período sem conturbações mais profundas, ainda quando suas rendas sofriam recessos significativos e "os impostos que incidem nos gêneros de exportação, no consumo das mercadorias e na venda dos cereais, estão quase nulificados, tal é a estagnação atual do nosso comércio" (Brandão 1921: 1).

Por essa razão, a conjuntura política foi favorável, sobretudo quando o estado interviu para que efeitos positivos sobre o cotidiano da região fossem atingidos de diversas formas. Além de o governo estadual manter-se atento às reivindicações da burguesia por meio do Congresso das Municipalidades, foi implantada a iluminação elétrica em Floriano, ${ }^{14}$ bem como construída a estrada de rodagem que interliga esta cidade a Oeiras, essencial ao setor do comércio importador-exportador e por retirar as mesorregiões sudoeste e sudeste do Piauí da condição de quase isolamento. Aliás, é de 1920 o primeiro relato publicado em O Popular de passeio entre as duas cidades, realizado em automóvel particular. O referido texto assinado pelos editores anuncia o trecho como possível de ser percorrido em 3 horas, "logo que sejam terminados os pontilhões, bueiros e as pontes dos rios Piauí e Salinas". ${ }^{15}$

Sintoma da progressiva abertura de estradas carroçáveis ligando cidades, esse tipo de crônica de viagem ou de passeio automobilístico, divulgada na imprensa piauiense, era uma novidade que ao longo dos anos conquistou as colunas jornalísticas, a despertar interesse pelas características lúdica e informacional que o gênero encerrava. Em Parnaíba, um dos relatos mais antigos remete ao ano de 1928, quando os escritores José Pires de Lima Rebelo, Edison Cunha e Benedito dos Santos Lima realizaram o trajeto compreendido entre Parnaíba e Viçosa do Ceará, ocasião excursionista em que conheceram o Gabinete Viçosense de Letras. ${ }^{16}$ 


\section{Horizontes literários}

Assim como era de praxe do periodismo desde o período oitocentista, a redação de 0 Popular também foi ponto de afluência aos escritores que residiam em Floriano ou em suas redondezas, dentre os quais Antônio Ribeiro Gonçalves, jornalista e médico amarantino que durante alguns anos clinicou na cidade. Suas páginas, portanto, testemunham a formação de Floriano como cidade letrada, configurada por escritores e um público leitor (embora reduzido), que aos poucos se rendiam a sociabilidades com aparelhos e hábitos ligados ao simbólico - o que, sem dúvida, alimentou a sua relativa vida literária. São os casos do Cine Ideal (empresa Genésio Leite \& Santos), do Cinema Florianense (empresa Nogueira \& Carvalho, que estreou sua primeira projeção em 31 de agosto de 1919) e do Recreio Florianense, espécie de clube-teatro que promovia espetáculos e saraus lítero-musicais sob a direção do padre Lindolfo Uchôa, e dramas, muitos dos quais com a presença de artistas e personalidades de outros estados. Neste espaço também ocorriam recitais, onde jovens declamavam versos alheios ou de própria autoria. Na passagem dos anos de 1910 a 1920, comuns eram declamações de José Silva, B. Portela e Avelino Rezende, bem como apresentações da banda de música "Euterpe Florianense".

No ano de 1921, uma sociedade fora formada para edificar um prédio específico ao funcionamento de um teatro. Ela era constituída por José Álvaro dos Santos, Nelson Cruz, padre Lindolfo Uchôa, Tírso Ribeiro Gonçalves e Luiz Oliveira. Instalado no Centro, a casa de espetáculos recebeu o nome Politeama, congênere ao do principal cineteatro de Pernambuco construído na cidade de Goiana, em 1914. Antes de ser incorporado ao dicionário como uma casa de diversões para apresentação de espetáculos, o neologismo, segundo comenta Fernando Morais, é incerto, mas os burburinhos da história popular pernambucana atribuíam o batizo da empresa "como uma forma pouco sutil encontrada pelo dono para [cortejar Maria da Penha Lins de Barro Guimarães, a Poli, uma das moças mais bonitas de Recife], já que o nome poderia também ser lido como 'Poli te ama'" (Morais 1999: 83). A referência nominativa não deixa de ser mais um dos fortes vestígios de influência e vinculação da classe política e intelectual do Piauí a Pernambuco.

Tais sociabilidades culturais fizeram com que Floriano, ainda nesse recorte, recebesse a visita de escritores que ajudaram a instituir alguns hábitos, dentre os quais o das conferências literárias, em um momento de grande projeção desse gênero. É o caso do escritor e antropólogo baiano Benedito Odilon Profeta, que ofereceu um ciclo de palestras públicas ao município entre os meses de maio e junho de 1919. Notas publicadas em O Popular dão conta da novidade com um público rarefeito, desacostumado: "A concorrência foi diminuta, e o senhor Profeta, apesar de ter falado bem, pouco resultado colheu dos seus ingentes esforços" ${ }^{17}$ e a explicação do jornal para o malogro era que a população "já está muito 'esfolada' com as quermesses". ${ }^{18}$ Curioso ainda atentar para a temática da palestra a que se referiam os redatores, "Feminismo no Brasil", cujas notas ainda eram muito tímidas no país frente à grande resistência encontrada no próprio meio intelectual.

Além de Odilon, registra-se em fevereiro de 1921 a visita do escritor piauiense Joaquim Nogueira Paranaguá, autor do relato de viagem Do Rio de Janeiro ao Piauí pelo interior do País 
(1905), quando de sua campanha ao cargo de deputado federal. Nesta ocasião o acompanhava o filho Correntino Weguelin Nogueira Paranaguá, que mais tarde legaria à história das letras piauienses o livro Terra de um paladino (1980). Os Paranaguá eram uma das famílias que no genérico sul do estado tinham suas bases políticas reforçadas pelo poderio de vastas propriedades rurais. Incitado pelos intelectuais de Floriano, Joaquim Nogueira proferiu na sede da "União Artística Operária Florianense" uma conferência cujo tema também estava na ordem do dia: o alcoolismo, "terrível intoxicador que atrofia grande parte do nosso povo". ${ }^{19}$

Tais registros são apenas alguns dos muitos que ajudam, em paralelo aos aparelhos de sociabilidades que se tornavam comuns, a acompanhar as transformações no modus vivendi dos jovens citadinos, em diálogo com a modernidade e as intermitentes, embora progressivas, atividades da vida literária.

Ainda dentro do recorte de investigação que interessa ao universo das letras, no campo do sistema escolar a cidade contava com o Colégio Nossa Senhora de Lourdes (dirigido por Estefânia Conrado), o Colégio S. S. Virgem e o Colégio 24 de Fevereiro, este mantenedor da revista 0 Livro, que tinha em sua redação o diretor, padre Lindolfo Uchôa, e alguns professores, dentre os quais Otoniel Beleza e Hosternes Brandão. Tudo indica que o referido periódico resistira por sete anos, com o encerramento de suas atividades em 1923. Parte dos redatores desse periódico colaborou, de maneira esporádica, em outros veículos de imprensa, é o caso do professor Hosternes Brandão, que no ano de 1919 escrevia artigos sobre os desdobramentos do pós-guerra para o jornal 0 Popular.

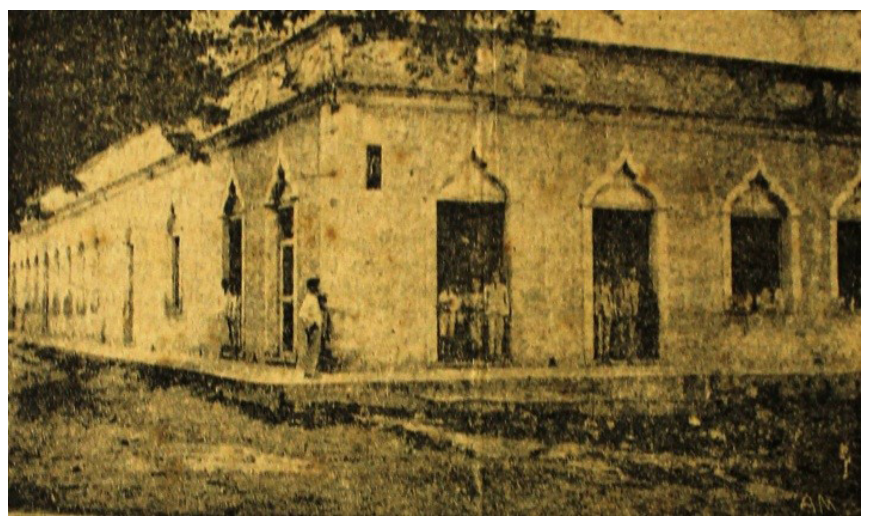

Na fotografia, prédio do Colégio 24 de Fevereiro, em Floriano, Piauí, em 1922.

(Fonte: O Livro, ano 7, n. 62, 19 nov. 1922. Acervo: Projeto Memória do Jornalismo Piauiense, UFPI).

O Lírio é também o nome de uma revista literária estudantil, fundada em 1914 e mantida pelo Grêmio Literário 11 de Agosto. Foi seu redator-chefe o estudante Hugo Vítor Guimarães, na época com 17 anos, colunista de ensaios históricos no periódico; e gerente, Pedro Guimarães. $\mathrm{O}$ corpo redacional dessa folha indicia uma relativa organização e reunião de letrados em torno de uma marca, a formar pequenas "tribos" literárias ou, ao menos, uma comunidade discursiva, 
como quer Maingueneau (2001); eram eles: Cícero Neiva, Gomes Sobrinho, Benedito Araújo, Gerson Ernestino, Fábio Paraguassú, Cristóvão Soares, Costa Rosal e Raimundo Ramos.

O mesmo ocorre em 9 de novembro de 1919, quando é fundado o jornal humorístico e literário 0 Farol, o segundo com este nome no Piauí. ${ }^{20}$ Era seu diretor Mário Vieira da Mota e, segundo nota de $O$ Popular, a folha tinha "como colaboradores diversos rapazes do nosso meio social", ${ }^{21}$ a revelar, mais uma vez, a formação mínima de um grupo intelectual em torno de um objeto literário-jornalístico.

O Popular também noticia a existência da "Agência Americana", casa comercial que negociava de tudo, de joias a manteigas, roupas e ferragens e, em 1919, fornecia à população de Floriano livros didáticos e literários. A listagem de seus títulos anuncia, de maneira parcial, os autores e os materiais que estavam em voga no sistema intelectual e escolar da cidade, sobressaindo-se nas devidas áreas de conhecimento autores de reconhecido mérito nacional: para os Estudos Cívicos, Olavo Bilac e Coelho Neto; Gramática Portuguesa, Alfredo Gomes, Carlos Pereira e João Ribeiro; Aritmética, J. Viana e Antônio Bandeira Trajano; História do Brasil, também a cargo de João Ribeiro.

A escassez de notas ou anúncios a respeito da comercialização de livros é um indicativo, embora não totalmente seguro, de que esse tipo de produto, sobretudo do gênero literário, era de pouca circulação - circunscrito, talvez, a uma reduzida classe intelectual em atividade. Aliás, o número de assinantes que o jornal 0 Popular fazia questão de listar em suas páginas, menos de uma dúzia, ${ }^{22}$ também serve de fonte vestigial, apesar de não representar uma quantidade concreta, posto a folha ter tido venda avulsa. A hipótese, porém, pode ser reforçada a partir de uma prática que, consequente a essa circunstância de diminuto público, se tornou comum: a filança de livros. No Piauí, a prática começou a ser denunciada por Higino Cunha em suas Memórias (1940), ao dedicar capítulo sobre o problema que sofrera em Teresina no início do século XX e, a seu ver, uma das consequências do analfabetismo: "o desequilíbrio existente entre a oferta e a procura de livros publicados no Brasil provém do fato de que o público brasileiro ainda não se acostumou a ver no livro uma mercadoria como outra qualquer" (Cunha 2011: 85).

Com um mercado reduzido, reduzida ficava a oferta e rara a circulação do produto, daí a razão do reclame público dos editores de $O$ Popular, cuja prática vitimara a sua própria redação: "ao cidadão que teve a amabilidade de levar desta Redação, para ler, os livros - Conspirações, por Dantas Barreto, Coisas da vida, de Alfredo de Assis, e Zodíaco, de Da Costa e Silva, pedimos o obséquio de devolvê-los". ${ }^{23}$ Entre um escritor pernambucano e um maranhense, a nota indicia a leitura literária do amarantino Da Costa e Silva, já nesse ano de 1919, poeta de reconhecido êxito nacional em periódicos brasileiros, dentre os quais 0 Malho e Careta.

De uma maneira ou de outra, e fazendo frente a um quadro reduzido de leitores, 0 Popular cumpriu o papel de promotor da leitura, incentivo que ia além do consumo de suas páginas: a folha apoiava iniciativas que, de forma substanciosa, contribuíram no combate ao analfabetismo, a citar a "Aula Davi Caldas", núcleo escolar noturno gratuito da União Artística Operária, fundada em 1920 e que neste mesmo ano contava com mais de 100 crianças matriculadas. 
Como prática recorrente, pertenciam ao quadro societário alguns escritores, a citar os poetas João Francisco Ferrí e José Vidal de Freitas. ${ }^{24} \mathrm{Em} 1^{\circ}$ de maio do ano seguinte, a própria União Artística Operária lança o periódico Jornal Falado dos Artistas (com programa literário, crítico e noticioso). A ideia era que a venda da audição do jornal auxiliasse com os gastos de construção do prédio da referida instituição de ensino. Mais tarde, em julho de 1921, a iniciativa recebeu oitenta volumes de livros voltados para a educação primária, ofertados pela Livraria Francisco Alves, do Rio de Janeiro, que sensibilizada com o pedido feito pelos dirigentes da União Artística, realizou a doação em homenagem ao primeiro aniversário dessa sociedade.

Ademais, 0 Popular, ao abrir espaço para textos de autores conhecidos, ajudava a ampliar os horizontes de leitura que detinham seus conterrâneos, além de investir na promoção do livro. É o caso da crônica "Amai o livro", do escritor ludovicense José Augusto Correia (um dos mais publicados na folha entre os anos de 1918 e 1919), estampada na capa de uma das edições desse jornal, de onde se extrai o seguinte trecho de evocação sentimental: "quanto erro há em desprezar ou tratar com indiferença o bom livro!" ${ }_{25}$ Em um meio de poucos leitores e onde a leitura não havia se consumado como hábito, o texto parecia não encontrar endereço mais preciso, ainda quando em certos momentos indicava leituras para todos os gostos, a diferenciar, nesse exercício, o que seria boa leitura da má:

Amais a Astronomia? Aí tendes facilmente de Flamarion a História do Céu, a Atmosfera, a Pluralidade dos mundos habitados, e muito mais, de Arago a Astronomia Popular, além de outros sábios.

Amais as Matemáticas - Lede Bourbon, Bertrand e tanto mais.

Amais o estudo da vossa língua? Procurai Rui, Ernesto Carneiro, Sotero, Candido Figueiredo e essa legião que estudo o idioma de Camões.

Amais o próprio romance, o conto? Tendes Coelho Neto, Alencar, Victor Hugo e centenas mais. Enfim, seja qual for a vossa inclinação, seja qual for a profissão escolhida, encontrareis muitos amigos em ótimos livros, que vos darão gozos inefáveis. (Correia 1919: 1)

Ao lado do jornalista Gonçalves Maia, redator do Jornal Pequeno, José Augusto Correia era um dos escritores com o maior número de textos reproduzidos em $O$ Popular desse período. Pela veia política, este escritor se ateve a assuntos congêneres e sua produção era abastecida pelos sentimentos mnemônicos de sua cidade e seu estado, São Luís, no Maranhão. Quanto a Maia, a reprodução de seus textos na folha pode estar vinculada às cordiais relações que esse pernambucano já há décadas estabelecera com os literatos piauienses: é o caso da amizade que alimentara com Taumaturgo Sotero Vaz, poeta natural de Amarante, cidade próxima à cidade de Floriano. No ano de 1893, em Recife, Gonçalves Maia foi um dos redatores do jornal O Equador, dirigido por Taumaturgo Vaz.

O Popular encontraria concorrência na imprensa somente em 2 de agosto de 1919, quando aparece o jornal Cidade de Floriano. Dirigido por Antônio Lemos e com a colaboração dos poetas João Francisco Ferrí, Heráclito Souza, Nelson Cruz e Dias da Cunha, esta folha era eminentemente 
política, mas suas páginas também estavam abertas e difundiam produções literárias, algumas das quais por meio de pseudônimos devido ao conteúdo crítico e satírico. É o caso de "Zé Vidente" e "A. L.", outro pseudônimo que com aquele alimenta polêmica na imprensa florianense. $\mathrm{O}$ referido embate cordial entre os dois escritores encontrou reverberação em Teresina quando, em 1921, o poeta e dramaturgo Jônatas Batista, editor de 0 Nordeste, inferiu comentário contra "A. L.", considerando-o "matuto". Esse tipo de situação demonstra que a intercomunicação entre os circuitos literários piauienses, neste caso o centro-nortista com o "sulista". Ao longo dos anos de 1920 outras polêmicas surgiram entre os articulistas e poetas, sendo a dos editores de 0 Popular com o poeta Dias da Cunha, de Cidade de Floriano, entre os meses de setembro e outubro de 1920, a que mais focou problemas estéticos, como a versificação.

Apesar dos embates literários, as duas folhas, em princípio, não eram adversárias, e os limites de suas relações, tecidos pelo espírito do companheirismo e da cordialidade. Em 1921, porém, suas edições escalaram um conflito que fragilizou a linha tênue do respeito mútuo: em 9 de janeiro um suposto ataque desleal proferido nas páginas de Cidade de Floriano a José Pires Ferreira, diretor-proprietário de O Popular, pôs fim ao regime de boa convivência.

Tudo indica que o confronto entre os periódicos obedecera à estrutura que constituiu a sociedade e o circuito literário florianense, pautado em interesses político-partidários e comerciais. Antônio Lemos engatilha a intriga ao levantar voz contrária ao status quo do controle político quase unânime praticado pelo Partido Republicano, e suas consequentes atividades comerciais. Atitude esta rebatida pelos redatores de 0 Popular:

Começou a escrever sandices contra uma companhia de vapores, e suas palavras não deram nenhum resultado; meteu-se a querer mudar nomes de ruas, não tendo o Conselho Municipal lhe dado a mínima importância ao que pediu; quis reformar a boa ordem do Hospital de Caridade e, enfim, tratou de mil coisas inúteis, a que ninguém prestou atenção. ${ }^{26}$

A nota indicia ainda a tentativa de Lemos em arregimentar na classe trabalhadora um nome capaz de concorrer ao pleito contra os ricos senhores de terra. Se por um lado o anseio de Lemos não surtira efeito devido ao engessamento dos indivíduos, claramente pacificados por um domínio estrutural e econômico e por estarem indiferentes à consciência plena de classe, por outro, o contra-argumento dos diretores de $O$ Popular parece esconder uma incipiente agitação proletária. A começar, essa classe trabalhadora estava organizada sob o signo de uma instituição, a "União Artística Florianense", ligada à União Artística Operária; a posteriori, ao procurarem reverter seu quadro de analfabetismo, os proletários, como dito, criaram, com recursos próprios e doados, um curso noturno e o nomearam "Davi Caldas", um dos jornalistas piauienses de viés revolucionário do século XIX, republicano extemporâneo, defensor da instrução pública e forte opositor às políticas oligárquicas experimentadas por inúmeras províncias brasileiras sob a benção do Império; e, por fim, a partir de seu poder associativo, os operários de Floriano criaram um jornal falado, sobrevalorizando a palavrada falada, como fizeram os antigos jornalistas revolucionários da França. O esforço e o grito de consciência de 
Cadernos de Literatura Comparada

Horizontes Comerciais, Políticos e Literários na Imprensa de Floriano entre os anos de 1902 e 1921

Antônio Lemos, portanto, não vinham ao acaso, por trás havia alguma centelha favorável de transformação, de transcendência. A história, todavia, mostra que, assolados pela oligarquia, ideias e levantes não puderam seguir adiante e rapidamente foram abafados pelos tribunos da imprensa escrita. Lemos, o jornalista com laivos de revolução e resistência às elites, terminara enxotado pelos correligionários do PRP e descrito com pilhéria pelos desafetos:

Na véspera das eleições houve encerramento das aulas na escola dos artistas denominada - Davi Caldas. O redator político da Cidade falou às massas, concitando os operários da União Artística Florianense a votar na chapa que aquele jornal apresentou ao eleitorado independente. 0 discurso do jovem Esculápio causou geral estupefação, pois aquela novel sociedade não tem nenhum fim político. Diante de tanta parvoíce, os membros daquela agremiação ficaram apavorados e, sem discrepância, votaram no dia seguinte na chapa governista, como prova de sua lealdade partidária. ${ }^{27}$

Tamanha virulência alcançou essa polêmica em Floriano, com direito a tentativa de empastelamento, que chegou às lides da imprensa teresinense, tendo o jornal o Piauí se manifestado a respeito. Além de órgão do Partido Republicano Piauiense, este periódico também tinha em seu quadro redacional Daniel Paz que, ao ampliar seus empreendimentos jornalísticos na capital do Piauí, arrendou, em 8 de janeiro de 1920, a tipografia do estado para a impressão desse órgão noticioso e político, e transferiu residência definitiva para Teresina. ${ }^{28}$

Porque representava um risco à estabilidade política, a malhação do nome de Antônio Lemos tanto em Floriano como em Teresina virou um escândalo, sobretudo por o diretor de Cidade de Floriano gozar de prestígio na sede do executivo estadual, herança dos tempos de atuação na imprensa teresinense por certo período, quando editou, em 1901, o hebdomadário 0 Livro, com a colaboração dos poetas Benedito Lemos e Poncion Caldas, filho de Davi Caldas. Como Lemos não dispunha de uma estrutura partidária ou mesmo econômica favoráveis, o embate era desigual, ainda quando as composições conservadoras aparelhadas no e pelo estado pouco espaço davam às vozes contrárias.

Em Teresina ecoavam em uníssono os interesses dos representantes de diversos grupos ligados às porções mais afastadas do Piauí, em especial do sudeste e do sudoeste. Estes se mantinham no centro administrativo estadual, integrados às esferas do legislativo, do judiciário e do executivo. $\mathrm{O}$ malogro da experiência de resistência política a um grupo dominante na política e com o controle de veículos de imprensa talvez explique a decisão de Antônio Lemos de abandonar Floriano em 1921, logo após a posse do novo intendente do PRP. Mais tarde, em 1926, em conjunto com outros intelectuais, Lemos refunda em Teresina o jornal Gazeta, em segunda fase, com uma linha independente e noticiosa - e com grande espaço para a produção literária.

A transferência de Antônio Lemos para Teresina também encerrou as atividades de Cidade de Floriano, fato este comemorado pelos diretores de O Popular e dirigentes do Partido Republicano. É o que demonstra a nota publicada em 13 de janeiro de 1921: "Floriano nada perdeu com a retirada do senhor Lemos; antes, pelo contrário, lucrou, vendo-se livre daquele espírito 
malicioso que, ligado ao um seu similar, queria chafurdar a política local, como se ambos fossem entidades de valor, quando nunca passaram de intrujões". ${ }^{29}$

Dois fenômenos, portanto, encerram o período aqui analisado e ambos estão vinculados à mudança de residência e interesses de dois dos principais intelectuais que atuaram na cidade, Daniel Paz e Antônio Lemos, diametralmente opostos. Isso talvez explique a imprensa em Floriano, nos anos seguintes, ter trocado o caráter combativo da política por um embate de ordem ultraconservadora. Nesse novo momento, o Popular, francamente alinhado aos preceitos da Igreja Católica, altera sua linha editorial e inicia uma série de ataques ao feminismo e aos padrões de comportamento ditados pela modernidade.

\section{NOTAS}

* Daniel Castello Branco Ciarlini é Doutor em Estudos de Literatura pela Universidade Federal do Rio Grande do Sul (UFRGS). Professor Adjunto I do Centro de Ciências Humanas e Letras da Universidade Estadual do Piauí, Brasil. Docente Permanente do PPGL/UESPI. Coordenador do Núcleo de Estudos em Sociedade, Imprensa e Literatura Piauiense e vice-coordenador do Núcleo de Estudos Literários Piauienses. Autor de Literatura, imprensa e vida literária em Parnaíba (2016).

${ }^{1}$ Este artigo foi desenvolvido a partir do acervo hemerográfico do programa Velho Monge, coordenado pelo Núcleo de Estudos em Sociedade, Imprensa e Literatura Piauiense (NESILPI), da Universidade Estadual do Piauí, campus Dra. Josefina Demes.

2 "A nossa navegação", O Popular, ano 10, n. 394, 13 mar. 1921, p. 2.

${ }^{3}$ Há inúmeras notas ao longo das edições de O Popular, de 1919 em diante, que noticiam o intenso fluxo de comerciantes tanto de uma como de outra praça em visita aos polos com os quais se ligavam - em um regime de cordialidade recíproca, mais do que com a própria capital do estado, Teresina. É o que mostra, por exemplo, a nota de 21 de novembro de 1920, ao comentar a visita de Constantino Correia a Floriano: "em propaganda de sua casa comercial, em Parnaíba, encontra-se nesta cidade o coronel Constantino Correia, cavalheiro muito estimado em nosso meio social" ("Viajantes", o Popular, ano 9, n. 379, 21 nov. 1920, p. 2). Por esse tempo, há em Floriano uma série de comerciantes que são agentes de firmas parnaibanas, a citar Artur Mouzinho, que agenciava a empresa Marc Jacob, esta que mantém negócios na cidade ao longo do século XX.

${ }^{4}$ No acervo hemerográfico do Centro Cultural Teodoro Sobral, em Floriano, consta, como última edição da folha, a de número 906, datada de 23 de dezembro de 1934, já em seu ano 23.

${ }^{5}$ Ref. Jornal de Caxias (1902), cidade de Caxias, no Maranhão; O Artista (1902) e Cidade de Teresina (1911), ambos de Teresina, no Piauí.

${ }^{6}$ As conexões parentais de Daniel Paz com o meio intelectual vão mais além: Higino Cunha e Abdias Neves, o primeiro, Procurador da Fazenda em 1911, o segundo, juiz substituto federal no mesmo ano, ambos fundadores da Academia Piauiense de Letras em 1917, eram casados com as primas de Daniel Paz. Não bastasse, no campo político, Antonino Freire, governador do Piauí no quadriênio 1910-1912, era primo de Miguel de Paiva Rosa. A complexa rede de articulações parentais não passava despercebida pelos periódicos piauienses, razão que fez o jornal o Apóstolo, ligado à Diocese piauiense, inferir se tratar, no Piauí, 


\section{Cadernos de Literatura Comparada}

Horizontes Comerciais, Políticos e Literários na Imprensa de Floriano entre os anos de 1902 e 1921

da "oligarquia dos Paz, e o atual governador é parente do senhor Miguel Rosa, sendo o pai do senhor Miguel Rosa (João Rosa) cunhado do senhor Manuel da Paz, diretor do Tesouro Estadual e membro da Comissão Executiva - 'Adeus Ética'” (O Apóstolo, ano 5, n. 238, 17 dez. 1911, p. 3).

${ }^{8}$ A gripe. O Popular, Floriano, PI, ano 8, n. 295, 12 jan. 1919, p. 2.

${ }_{9}^{9}$ Dados localizados desse mesmo periódico dão conta de que a primeira onda do surto da influenza conhecida como "gripe espanhola" teria se estendido no Piauí até por volta de fevereiro de 1919, quando então a curva de infecção demonstrou declínio e Teresina, até o início desse mês, com uma soma de 160 vítimas. Vale lembrar ainda que no início do mesmo ano o país entrara em comoção ao saber que o recém-eleito presidente, Rodrigues Alves, havia contraído a moléstia, falecendo poucos dias depois sem tomar posse do cargo. Como uma sequência de picos e depressões do surto sanitário, em março uma segunda onda epidêmica atingiu cidades como Rio de Janeiro, São Luís e, no Piauí, Parnaíba. Nesta, adoeceram importantes personalidades da imprensa e das letras do norte piauiense, a citar Melo Lula, padre apologeta que nos anos de 1910 atuou nas páginas do jornal O Apóstolo, em Teresina, contra as incursões intelectuais dos maçons no periodismo, e um dos iniciadores de Berilo da Fonseca Neves nas lides jornalísticas, quando em 1920 o convidou para o corpo redacional do jornal católico parnaibano $\mathrm{A}$ Boa Semente.

${ }^{10}$ Ref. "Um sol que tudo ofusca", o Popular, ano 8, n. 305, 6 abr. 1910, p. 1.

${ }^{11}$ Benjamim Augusto Freitas (presidente), Raimundo Ribeiro da Silva (vice-presidente), João José Ribeiro, Carlino Francisco Nunes, Vitor Martins e Raimundo Neves Ataíde.

${ }^{12}$ Raimundo Borges da Silva é o tipo que ilustra com precisão a estrutura de poder a que estavam atrelados os protagonistas do circuito literário sudoeste-sudeste do estado: sua atividade política era uma extensão do poderio como homem de posses - em Floriano, era proprietário da fazenda Matapasto, onde se reuniam, de tempos em tempos, sobretudo em períodos de festejos religiosos, a elite da cidade e o clero; e para onde era dirigida, a fim de animar as eventualidades, o aparelhamento munícipe, como a orquestra da banda de música "Euterpe Florianense". Para tal fim, contava a fazenda com uma "bela e espaçosa capela de São Sebastião, recentemente mandada construir ali por dona Janoca Borges [esposa do referido político]" ("Matapasto", 0 Popular, ano 10, n. 388, 30 jan. 1921, p. 2).

${ }^{13}$ Natural de Barras, no Piauí, liderou os piauienses da Colônia Piauiense instalada em Pernambuco logo após a morte de seu primeiro líder, José Manuel de Freitas. Foi presidente honorário da Sociedade União Piauiense, em Recife, e chegou a ser proprietário de Jornal do Recife e nomeador ministro do Supremo Tribunal de Justiça.

${ }^{14} \mathrm{O}$ fato ocorre em 1923, a partir de contrato firmado pela intendência, Antônio Luís de Arêa Leão, com Francisco Liebard, representante da Siemens Schuckert, empresa de engenharia elétrica alemã.

15 "Passeio a Oeiras", O Popular, ano 9, n. 372, 3 out. 1920, p. 2.

${ }^{16}$ Ref. "Da planície ao planalto: excursão automobilística de Parnaíba à hospitaleira cidade de Viçosa - Notas e informações", A Praça, ano 1, n. 27, 1 mai. 1928, p. 1.

17 “Conferências literárias", 0 Popular, Floriano, PI, ano 8, n. 311, 1 jun. 1919, p. 2.

${ }^{18}$ Ibidem.

19 "Doutor Nogueira Paranaguá", o Popular, ano 10, n. 390, 13 fev. 1921, p. 2.

${ }^{20} \mathrm{O}$ primeiro com esse nome foi fundado na cidade de Parnaíba, no ano de 1914, e tinha a direção do escritor Alarico da Cunha. Era um órgão da Maçonaria.

21 "O Pharol", o Popular, ano 8, n. 332, 23 nov. 1919, p. 2.

${ }^{22}$ Essa quantidade, ao que indica o percurso semanal da folha no ano de 1919 se amplia de maneira muito tímida, mas em comparação com o número inicial, se torna significativa já no primeiro semestre de 1920, ao ultrapassar os 90 assinantes. 
${ }^{23}$ Nota avulsa (sem título). O Popular, Floriano, PI, ano 8, n. 302, 16 mar. 1919, p. 2.

${ }^{24}$ Colaborador do jornal O Popular como auxiliar de oficina tipográfica, de 1916 a 1920, quando então migrou ao Recife para estudar no Colégio Americano Batista, que nos anos de 1910 teve como aluno Gilberto Freyre, e, nos anos de 1940, Ariano Suassuna.

25 "Amai o livro", o Popular, Floriano, PI, ano 8, n. 311, 1 jun. 1919, p. 1.

26 "A nossa posição: pretensiosos", o Popular, ano 10, n. 386, 9 jan. 1921, p. 2.

27 "A nossa posição: pretensiosos", o Popular, ano 10, n. 386, 9 jan. 1921, p. 2, grifo nosso.

${ }^{28}$ É nesse tempo que, impossibilitado de administrar duas folhas, Daniel Paz deixa a redação de O Popular e, reinstalado em Teresina, dedica-se ao o Piauí, periódico que já se encontrava em sua terceira fase. Em sendo Daniel o intelectual articulador da folha, com sua saída $O$ Popular perdeu a força de seu conteúdo local ou regional, bem como a participação constante de colaboradores de outras partes do país. José Pires Ferreira, para preencher essa falta, quadruplicou o espaço das notas telegráficas (muitas vezes a ocupar toda a primeira página do periódico) e concentrou parte do conteúdo do jornal em textos extraídos de outros periódicos brasileiros, sobretudo do Rio de Janeiro, cujos temas versavam curiosidades ou assuntos de ordem política. 29 “Farsa ou pilhéria?", O Popular, ano 10, n. 390, 13 fev. 1921, p. 1.

\section{Bibliografia}

Anderson, Benedict (2008), Comunidades imaginadas: reflexões sobre a origem e a difusão do nacionalismo, Tradução de Denise Bottman, São Paulo, Companhia das Letras.

Brandão, Hermano (1921), "Em prol da comuna", o Popular, n 402, Floriano, 1.

Correia, José Augusto (1919), "Amai os livros", o Popular, n³ 311, Floriano, 1.

Cunha, Higino (2011), Memórias: traços autobiográficos, Teresina, Academia Piauiense de Letras [1940].

Gandara, Gercinair (2010), Rio Parnaíba... Cidades-beira (1850-1950), Teresina, EDUFPI.

Lopes, Luiz Paulo (1997), Flagrantes de uma cidade, Teresina, Jolenne.

Maingueneau, Dominique (2001), O contexto da obra literária: enunciação, escritor, sociedade, Tradução de Marina Appenzeller, São Paulo, Martins Fontes.

Morais, Fernando (1999), Chatô: o rei do Brasil, a vida de Assis Chateaubriand, São Paulo, Companhia das Letras.

Neves, Abdias (1920), "Aspectos e perspectivas". o Popular, n 350, Floriano, 1.

Rego, Junia Motta Antonaccio Napoleão (2013), Dos sertões aos mares: história do comércio e dos comerciantes da cidade de Parnaíba, Teresina, EDUFPI.

Tajra, Jesus Elias/Tajra Filho, Jesus Elias (1995). "O comércio e a indústria no Piauí", in Piauí: formação, desenvolvimento, perspectivas, Teresina, Halley, 133-158. 